Journal of Transport and Land Use 1:2 (Fall 2008) pp. 51-88

Available at http://jtlu.org

JTLU

\title{
Seven American TODs: Good practices for urban design in Transit-Oriented Development projects
}

\author{
Justin Jacobson \\ Ann Forsyth \\ University of Minnesota $a^{a} \quad$ Cornell University $b$
}

\begin{abstract}
In the past few decades, Transit-Oriented Development (TOD) has emerged as a popular and influential planning concept in the United States. Physical design is an important aspect of making TOD projects work as it is a crucial means of coordinating relatively intensive land uses and multiple transportation modes. This paper analyzes seven American TOD projects in terms of urban design and concludes with a discussion of "good practices" for future TOD projects focusing on development processes, place-making, and facilities. This research supplements prior scholarship on TOD that has tended to focus on policy issues such as regulation and financing.
\end{abstract}

Keywords: Transit-Oriented Development; Urban Design.

\section{Introduction}

Transit-Oriented Development (TOD) projects depend on good urban design to coordinate transportation types, mix land uses, and create an appealing public space, all in a limited area. Scholarly attention, however, has been largely focused on the public policy aspects of TOD development such as planning strategies and financing options. Less attention has been paid to finding ways to overcome some of the inherent difficulties of TOD project planning, such as balancing different types of transportation modes. If TOD projects are to be successful and meet the goals of policy makers, transportation engineers, planners, and the general public, greater understanding of the successes and failures of TODs in terms of their urban design practices is needed. This paper analyzes urban design outcomes in seven American TOD projects to draw out "good practices" in urban design, focusing on development processes, place-making, and facilities. The seven projects offer valuable lessons for future TOD project implementation.

\footnotetext{
ajaco0676@umn.edu

${ }^{b}$ forsyth@cornell.edu
}

Copyright 2008 Justin Jacobson and Ann Forsyth.

Licensed under the Creative Commons Attribution - NonCommercial License 3.0. 
This paper contributes to discussions about TOD by drawing on a systematic comparative analysis of the urban design features of specific TOD projects that many (though not all) commentators consider to be good examples of urban design (Adams 1994; AIA 2002; Bernick and Cervero 1996; Leach 2004; Cervero 1998; Zucker 2003). Data were collected using audit tools, inventories, workshops (modified focus groups) with design experts and community- or government-based stakeholders, mapping, and traditional visual assessments. The study placed the sites in context through case histories. It then used the urban design assessment and cases to filter and revise the "best practices" advice given in important experience-based professional literature. In light of the context-dependent and unique nature of individual TOD projects, we offer a series of "good practices" with wide applicability. These guidelines can provide a next generation of advice for TOD design, emphasizing visual quality as well as a number of livability characteristics such as vitality and human scale.

\section{Transit-Oriented Development and Urban Design}

Development facilitated by transit is as old as transit technologies themselves. However, in the past few decades, TOD has emerged as a popular and influential planning concept in the United States. In the most basic terms, TOD is a strategy to integrate public transportation investments and land-use practices in order to create walkable, diverse neighborhoods in both center city and suburban settings. TOD principles have become influential among policy makers, urban planners, and transit officials. Projects have been implemented in a wide array of cities across the United States. This section introduces TOD, its history and implementation, and its relation to urban design.

\subsection{Definitions}

Proponents of TOD provide a variety of definitions of the concept and use a variety of terms including "transit villages" and "transit-friendly design" (Calthorpe 1993; TCRP 1997; Cervero 1998; Cervero, Ferrell and Murphy 2002; Parker and Meyer 2000; Tumlin et al. 2003; Dittmar and Ohland 2004). The definition advanced by architect and planner Peter Calthorpe is typical and conveys the basic themes of TOD: "A Transit-Oriented Development is a mixed-use community within an average 2,000-foot walking distance of a transit stop and core commercial area. TODs mix residential, retail, office, open space, and public uses in a walkable environment, making it convenient for residents and employees to travel by transit, bicycle, foot, or car" (Calthorpe 1993: 56). In a review of the various definitions for TOD, Robert Cervero, Christopher Ferrell, and Stephen Murphy write that while details vary, the core principle is to provide mixed-use development that is close to and well-served by transit, and furthermore, is conducive to transit riding (2002: 6). 
TODs can function in both center city and suburban settings, the main difference being the density in each place (Calthorpe 1993: 57). TODs are usually based on rail service (either light rail or commuter rail), but bus-based TODs also exist, as in the Uptown District of San Diego (Parker and Meyer 2000). TOD should also be distinguished from other types of land-use planning which, while involving transit to some degree, do not fully integrate transit and land-use planning. Such forms are generally referred to as Transit-Adjacent Development (Tumlin et al. 2003).

\subsection{History and Implementation}

Although Calthorpe, transportation scholar Cervero, and others deserve credit for formally introducing TOD and increasing its profile in the 1990s, the origins of TOD actually go back much further, as even Calthorpe and Cervero admit. In the nineteenth century, expanding rail and streetcar systems provided the infrastructure for transitoriented metropolitan development. In particular, the typical streetcar-oriented development patterns that defined many American cities, including Boston, Cleveland, and Philadelphia, serve as precursors for contemporary TOD (see Warner 1962). To a certain extent, the forms of these cities even today exhibit the legacy of land development based on mass transportation. The modern TOD concept also shares much in common with the idea of the "Garden City," from the dawn of the twentieth century, in which more or less self-sufficient suburbs are centered on commuter train stations (Howard [1903] 1985). The similarity between the contemporary idea of TOD and more traditional urban forms is strong, and in many ways, TOD is really a repackaging of what was for many years the typical form of center city and suburban development in the United States.

The revival of TOD has been spurred by dissatisfaction with some features of presently dominant land-use forms. Smart Growth advocates have argued that automobilebased suburbanization following the Second World War, while having a number of benefits, has caused some interrelated land use problems: economically declining cities; residential areas without retail or service opportunities nearby; and a lack of decent housing alternatives to the standard suburban house (Duany et al. 2000; Hayden 2003; Kay 1997). While being promoted as an improved land use pattern, TOD has been also touted as a better approach to transportation, with the argument that increased transit service can ease traffic congestion on highways, improve air quality and accommodate the needs of people for whom driving is either impossible or economically prohibitive. TOD has been seen as providing an opportunity to address land-use and transportation issues simultaneously (see Dittmar and Ohland 2004: 5-15). 


\section{The Role of Urban Design in TOD}

TOD seeks to accomplish a number of interrelated goals for different types of users. Ideally, TODs provide places for people to live, work, shop, and relax. Affordable housing often has a prominent place in TODs-households with low or moderate incomes are attracted to transit access and are likely to own fewer cars and occupy more space efficient dwellings, meaning that they can take full advantage of the transit orientation. While transit is essential to TODs, access for pedestrians, bicyclists and automobiles is also important (Dittmar and Ohland 2004; Calthorpe and Fulton 2001; Seigman 2003; Transit Cooperative Research Program 1997; Tumlin and Millar-Ball 2003). Aesthetically, the ideal TOD is inviting and attractive to many types of users, acknowledging that people have different standards and different reasons for using the same space. TOD designers need to address these varied concerns in ways that do not sacrifice economic efficiency or conflict with larger community goals.

Urban design - the design of the built environment beyond the scale of the building, typically focusing on blocks, neighborhoods, or districts—can be a key mechanism for achieving this balance. As with any urban design project, a well-executed design can bring together diverse functions and users, whereas good intentions with poor design execution can wind up being no improvement, or possibly even a detriment, to the central city or suburban surroundings (Cooper Marcus and Sarkissian 1986; Cooper Marcus and Francis 1998; Jacobs and Appleyard 1987; Lynch 1981; Whyte 1980).

Many features of TOD (and, indeed, much of the discussion of TOD in the academic literature) are at a planning or policy scale; relevant features at this scale include frequency of transit service, pricing, equity, development mechanisms, and regulation (e.g. Cervero 1994; Dumbaugh 2004). Others deal with regional planning (e.g. Calthorpe and Fulton 2001). However, the urban design stage of a project is where the goals and ideas of TOD are fitted to real-world constraints of space, time, and money. Yet scholarly attention to detailed, site level urban design issues inherent in TOD has been minimal, with only a few key works (Calthorpe 1993; Seigman, 2003; Dittmar and Poticha 2004; Dunphy et al. 2004). Prior to analyzing the study sites in this research, we reviewed existing literature and grouped the urban design issues into twelve dimensions clustered in three categories: processes, places, and facilities. Table 1 outlines these dimensions of urban design and place-making as well as examples of how they are handled in the TOD literature.

From a design perspective, this matrix provides two lessons. First, some issues are mentioned but still pose many unanswered questions. This is particularly true of processes such as managing the development of a TOD over time and facilitating public engagement. In terms of development over time, these authors and others in the broader urban design field recognize that TODs will grow as the numbers of riders, residents, and shoppers increase, but do not address the question of how future growth 
can be factored into the TOD design stage. In addition, while a number of authors indicate the importance of mixed income housing to increase the use of transit (Dittmar and Poticha 2003; Dunphy et al. 2004), there has not been as much attention to the role of such housing in participatory processes in a TOD context.

Table 1: Examples of Urban Design Dimensions of TOD in Existing Literature.

\begin{tabular}{|c|c|c|}
\hline Dimension & Example guideline or approach & Comment \\
\hline \multicolumn{3}{|c|}{ Processes: } \\
\hline Time & $\begin{array}{l}\text { Design with short-term and long-term time- } \\
\text { frames in mind, because places, the peo- } \\
\text { ple who visit them, and the activities visi- } \\
\text { tors perform change over time. The possibil- } \\
\text { ity of future growth should also be consid- } \\
\text { ered. Dittmar and Poticha call this "Design } \\
\text { for change" (2004: } 32) \text {; Seigman notes that } \\
\text { good design means "allowing uses to change } \\
\text { easily over time" (2003: } 17) \text {. }\end{array}$ & $\begin{array}{l}\text { Little discussion about } \\
\text { managing design character } \\
\text { over development periods } \\
\text { that can last decades }\end{array}$ \\
\hline $\begin{array}{l}\text { Engagement } \\
\text { with public }\end{array}$ & $\begin{array}{l}\text { Include various stakeholders in the design } \\
\text { stage and use visioning and communication } \\
\text { processes to elicit design ideas and create the } \\
\text { design plan (Dunphy et al. 2004; 171). }\end{array}$ & $\begin{array}{l}\text { While broad public partic- } \\
\text { ipation is celebrated in the } \\
\text { academic literature, there is } \\
\text { little research on very di- } \\
\text { verse publics, however. }\end{array}$ \\
\hline Programming & $\begin{array}{l}\text { Programming means planning events and } \\
\text { activities in public spaces. For example, } \\
\text { concerts, flea markets, farmer's markets, art } \\
\text { shows, outdoor theater and the like help } \\
\text { "bring people and vitality to the area" (Dun- } \\
\text { phy et al. 2004: 176). }\end{array}$ & $\begin{array}{l}\text { There is much discussion } \\
\text { about mixed use and street } \\
\text { life, much less on program- } \\
\text { ming. }\end{array}$ \\
\hline Maintenance & $\begin{array}{l}\text { Understanding and budgeting for mainte- } \\
\text { nance requirements, especially in terms of } \\
\text { landscaping and greenery, should be part } \\
\text { of the design process. "Manage the invest- } \\
\text { ment" in order to ensure long-term success } \\
\text { (Dittmar and Poticha 2004:31). }\end{array}$ & \\
\hline
\end{tabular}




\begin{tabular}{rrr}
\hline Dimension & Example guideline or approach & Comment \\
\hline Places: &
\end{tabular}

Scale Emphasize design at a human scale, meaning one based on comfortable walking distances between points. Specifically for TOD, this means development within a quarter mile or a five minute walk radius (doubled for major stops) with placement of homes near transit at sufficient density; provide transitsupportive regional design (Seigman 2003; Dittmar and Poticha 2004).

Public spaces for human use Individual parts of the overall design should be designed with human activity in mind with "public spaces the focus of building orientation and pedestrian activity" (Calthorpe 1993: 43; Seigman 2003; Dittmar and Poticha 2004).

Safety Safety is a foundation of creating inviting public spaces and can be addressed through a variety of mechanisms. These include physical measures such as good lighting to avoid dark spots and encouraging "a variety of residential uses to ensure round-the-clock activity" (Dunphy et al. 2004: 176).

\begin{tabular}{|c|c|c|}
\hline $\begin{array}{l}\text { Variety and } \\
\text { complexity }\end{array}$ & $\begin{array}{l}\text { Attractive public spaces tend to be diverse, } \\
\text { colorful and interesting ones that avoid } \\
\text { monotony, either in terms of how they look } \\
\text { or how they are used. Designers should } \\
\text { pay attention to the social, visual, and land } \\
\text { use dimensions of complexity in the design } \\
\text { process (Dittmar and Poticha 2004: } 25 \text {, } \\
31 \text { ). Development and planning approaches } \\
\text { should "encourage every price point to live } \\
\text { around transit" (Dunphy et al 2004: 181). }\end{array}$ & $\begin{array}{l}\text { Variety and complexity in- } \\
\text { cludes social, land use, and } \\
\text { visual dimensions though } \\
\text { these may need different } \\
\text { design supports }\end{array}$ \\
\hline
\end{tabular}

This is a key dimension; the focus is environments where uses are close together rather than the finergrained issue of design of buildings and spaces to be human-scale.

Focus is on urban form rather than design details. 


\begin{tabular}{|c|c|c|}
\hline Dimension & Example guideline or approach & Comment \\
\hline \multirow[t]{2}{*}{ Connections } & $\begin{array}{l}\text { Average block perimeter limits (e.g. Seigman } \\
\text { 2003: } 17 \text {, proposed } 1,350 \text { feet) to create } \\
\text { "a fine-grained network of streets, dispersing } \\
\text { traffic and allowing for the creation of quiet } \\
\text { and intimate thoroughfares" (also Calthorpe } \\
\text { 1993: 43). }\end{array}$ & $\begin{array}{l}\text { Pedestrian-friendly street } \\
\text { networks are a major focus } \\
\text { of TOD guidelines. }\end{array}$ \\
\hline & Facilities: & \\
\hline $\begin{array}{l}\text { Pedestrian/non- } \\
\text { motorized } \\
\text { orientation }\end{array}$ & $\begin{array}{l}\text { Signal timing, traffic calming, etc. support } \\
\text { non-motorized transportation. Attended } \\
\text { bike stations at major stops; secure parking } \\
\text { at more minor stops (Seigman 2003: 17). }\end{array}$ & $\begin{array}{l}\text { Transit development needs } \\
\text { to support access from non- } \\
\text { motorized modes. }\end{array}$ \\
\hline $\begin{array}{l}\text { Transit in the } \\
\text { urban pattern }\end{array}$ & $\begin{array}{l}\text { Transit stops should be "attractive, comfort- } \\
\text { able, and sheltering" as well as well-located } \\
\text { (Dunphy et al. 2004: 180). }\end{array}$ & $\begin{array}{l}\text { Bus and train transit con- } \\
\text { nections can be key (Dun- } \\
\text { phy et al. 2004) }\end{array}$ \\
\hline $\begin{array}{l}\text { Car movement } \\
\text { and parking }\end{array}$ & $\begin{array}{l}\text { Minimum parking requirements are elimi- } \\
\text { nated; maximum parking requirements are } \\
\text { added (Seigman 2003: 17). Other options } \\
\text { include shared and structured parking (Dun- } \\
\text { phy et al 2004: 175). }\end{array}$ & $\begin{array}{l}\text { Authors vary in how mo- } \\
\text { torized modes should be ac- } \\
\text { commodated. }\end{array}$ \\
\hline
\end{tabular}

Second, some of the design features described by the dimensions are difficult to reconcile with one another. For example, in TOD areas where transit access is presumed to be frequent, there should be "quiet and intimate" thoroughfares, as well as access for bicyclists and, finally, some allowances made for automobiles (Seigman 2003). Accomplishing all this in a confined space of a quarter-mile, or even a half-mile, obviously entails some complicated choices between the needs of different types of transportation modes, as increased efficiency for one mode may come at the expense of another mode's users. The high density that characterizes TOD further increases the possibility of less-than- perfect trade-offs. Design can help make some features of higher densities fit into an existing, less-intensively-developed context and bring amenities that provide benefits for existing and new residents.

Transit planners, planning officials, real estate developers, community organizers and many other stakeholders have had to deal with such design issues in the implementation of TOD projects in the United States. Given that the particular circumstances of TOD projects are widely varied, so too are the solutions undertaken at the design scale. Yet, in analyzing the urban design characteristics of a number of TOD projects, it is clear that there are some solutions that work better than others, and that there are lessons to be learned from past experiences. 


\section{Methods}

This study analyzed seven TOD projects in the United States using six different types of urban design assessment tools in order to evaluate existing guidelines for TOD and reformulate a series of "best practices" for urban design (see Tables 1 and 2; Forsyth et al. 2007; forthcoming). The case study locations were: Rosslyn, Clarendon and Ballston in Arlington County, Virginia; the Delmar Loop in Saint Louis, Missouri; Emerson Park in East Saint Louis, Illinois; and Oakland City Center/12th Street and Fruitvale in Oakland, California. The seven sites were chosen to demonstrate a range of different types of TOD, recognizing that they are not a truly representative sample of all TOD projects in the United States. The study team selected the cases through an iterative process: developing a comprehensive list of transit examples; finding those that had some base of evaluation or description; then selecting examples to show a range of circumstances. Differences between the seven cases include (also see Table 2):

- Geographical location: Three projects are on the East Coast, two in the Midwest and two in the West. In addition, there are central city (Oakland City Center) and suburban locations (Ballston).

- Period: Each of the developments is still a work in progress, but some started their main development earlier, such as Rosslyn (1970s), while others are more recent, such as Fruitvale (1990s).

- Dominant land-use type: For example, commercial in Ballston and Delmar Loop; residential in Emerson Park.

- Levels of Affluence: Typical household incomes are higher in the Northern Virginia cases; lower in the St. Louis area cases. Lower-income housing was prominent in two of the sites (Emerson Park and Fruitvale).

- Scale of Development: Large-scale retail and offices dominate Rosslyn; smallscale retail and offices characterize Delmar Loop.

- Roles of PlanNers and DeVelopers: Non-profit developers were key in Emerson Park and Fruitvale; professional planners and economic development experts played a strong role in the Arlington, Virginia cases.

In addition to this analysis in terms of urban design, the seven sites could be examined from other perspectives. For example, they demonstrate mixed-use development (except perhaps Emerson Park), have economic impacts, contribute to local housing markets, and have involved public and private sectors in planning and construction. In order to keep the focus on urban design, however, such concerns are not dealt with 
here, though future research could well pay attention to such issues, or to other cases. Overall, this focused survey on design highlights a range of themes and issues that are important in themselves and also raise questions for later, further study.

Table 2: Case Studies Compared.

\section{Washington, D.C. Area}

Comments: The Washington, D.C. Metro is an older and well established transit system. Arlington County had conducted extensive planning to support Metro, including regional planning and public participation processes, and encouraged relatively intense development around the stations.

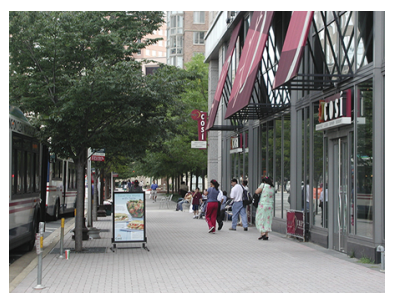

Rosslyn: The Rosslyn station is the gateway to Arlington County on Washington Metro's Orange Line, and the easternmost station in the Arlington TOD corridor.

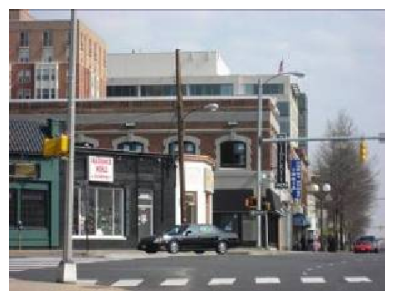

Clarendon: The first plan to specifically deal with Clarendon was released in 1984 and articulated a vision for Clarendon as an "urban village," meaning greater development around the station while maintaining the residential neighborhood away from the station.

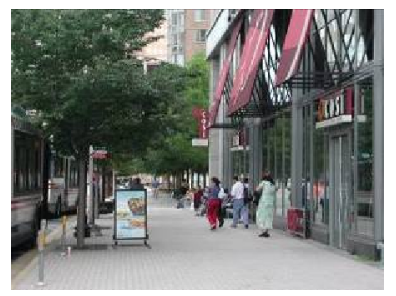

Ballston: The Ballston station area includes significant office and retail areas, as well as a wide variety of housing options. It is notable for the diverse mix of uses in this area. 


\section{East Saint Louis Area}

Comments: The East Saint Louis MetroLink LRT is newer. Compared to the three Virginia cases, the intensity of development is typically moderate and planning has been fragmented. Citizen activism has been important, as have been key institutions such as universities.

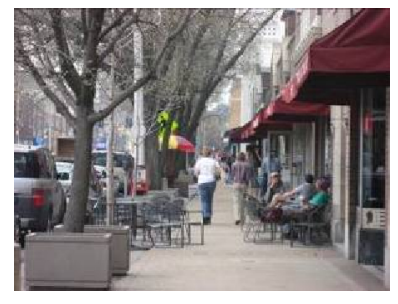

Delmar Loop: The introduction of MetroLink to this area preserved and extended the existing commercial activity from University City across the municipal border to the station in the City of Saint Louis.

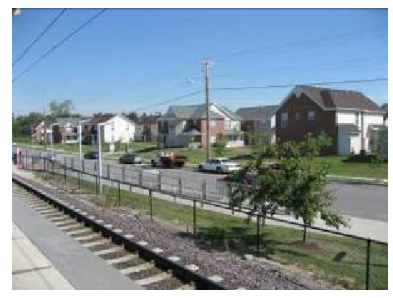

Emerson Park: In Emerson Park, TOD was brought to the area through community activism and has been used to spark redevelopment, especially of the housing stock, in the economically troubled City of East Saint Louis. Non-profit developers have played an important role.

\section{Oakland Area}

Comments: The Bay Area Rapid Transit (BART) system has taken a long time to spur development in some areas. The Oakland cases provide interesting examples of TOD's role in redevelopment at different development intensities.

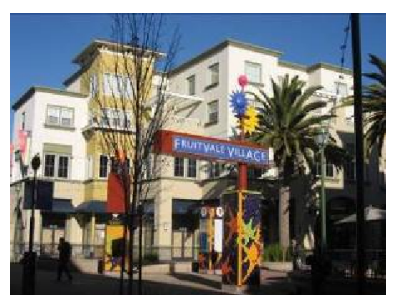

Fruitvale: The proposal for a transit village at Fruitvale in Oakland grew out of a disagreement between BART and Fruitvale community leaders over the construction of more parking lots in the area. The result is a mixed-use center of small-scale retail and apartments.

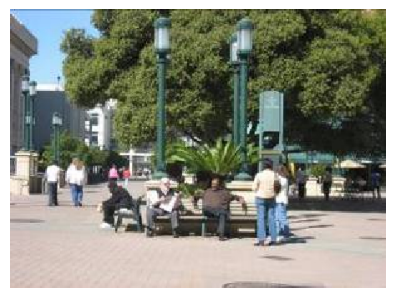

Oakland City Center/12th Street: Oakland's downtown has different parts with distinctive characters. This ongoing transformation demonstrates the challenges and benefits of implementing TOD in an intensely developed, already established area. 
The six methods for analyzing the seven case studies are discussed in much greater depth in a companion article (Forsyth et al. under revision), but are described here briefly. They represented a typical range of methods including (a) expert field checklists with quantifiable indicators, (b) participatory assessments with more qualitative findings, and (c) analyses developed from existing data such as maps and photographs. They also reflected systematic approaches based on theories of urban design (aesthetics, sense of place, perception) and more direct assessments by users and designers. The six methods were:

An Urban Design Score Sheet (Ewing et al. 2005, 2006) assessed walkable, mixed residential and commercial environments such as those advocated by TOD planners. It provided scores on several dimensions including imageability (creating a memorable place), enclosure (providing the sense of an outdoor room), human scale, transparency (providing views to activity), and complexity (providing visual variety).

An Urban Design Inventory, adapted from the Irvine Minnesota Inventory (Day et al. 2006; Boarnet et al. 2006) documented the presence or absence of dozens of key components of the urban landscape including the dimensions of ease of movement, pleasurability or overall attractiveness, and perceived safety. For many features it roughly assessed quality, but without the detail of the score sheet. Its approximately 160 questions can be combined to create indicators of different urban design concepts.

Design Workshops, a participatory evaluation technique with local experts in the design fields focused on seven questions about the designs' characters, strengths and weaknesses, memorable aspects, and how well the designs took advantage of the transportation infrastructure. Experts were divided from lay people because the former tend to like more experimental aesthetics than the latter (Stamps 1999; Sanoff 2000).

Community Representative Workshops were a participatory evaluation technique with representatives from city governments, members of community groups, transit users, police officers, transportation workers, and other professionals. There are many excellent participatory design techniques that focus on affecting actual design projects. However, they involve a great deal of effort on the part of participants and raise expectations about change. Instead, we chose a less onerous method that mirrored the design workshop method (descibed above), allowing us to compare the groups of experts and community representatives (Nick Wates Associates n.d., Sanoff 2000; Sarkissian et al. 2003; Urban Places Project 2000).

GIS-based Analysis of street networks and levels of mixed uses examining figureground relationships and intersection densities (Jacobs 1993; Southworth 1997; Forsyth 2005). Intersection densities are a measure of street connections-more intersections mean more options for moving around the area. In addition, we tallied the number of businesses in the case study areas, because they represent key destinations that people could visit. 
Photographic Visual Assessment was used to compare and contrast different projects, focusing on six issues: color contrast, form contrast, line contrast, texture contrast, scale contrast, scale dominance, and spatial dominance. This approach was based on work on visual impact assessment of transportation projects that reached a high point in the 1970s and 1980s (Shepphard and Newman 1979; FHWA 1988).

The major results are outlined in the cases that follow and in a subsequent summary. These results were used as a filter for assessing the best practices literature, allowing the team to develop the best practices principles that form the conclusion to this paper.

\section{The Case Studies}

\subsection{Rosslyn}

\section{Background}

In the 1960s, northern Virginia across the Potomac River from Washington D.C. was an economically depressed area characterized by marginal uses such as warehouses and struggling light industrial sites. Unlike many cities that drew on urban renewal funds to level such structures and build new highways, Rosslyn launched what can be considered the first of the new (postwar) generation of TOD projects. The Rosslyn Sector Plan, completed in 1977, provided greater freedom to private developers at higher (and hence, more profitable) densities as long as future developments conformed to the County's larger planning vision of mixed-use development based on the recently built transit system (WMATA launched Metro service in 1976). Key to this strategy was the use of "incentive zoning," through which developers received density bonuses in return for including particular features, like public plazas or allowances for bus stops, in their plans (Ward 1991; Henry 2006a). Due to this long-term development strategy, Rosslyn is now one of the region's premier locations for commercial and high-density residential uses; it contains almost eight million square feet of office space, almost 5,000 residential units, and over 2,000 hotel rooms (Arlington County Department of CPHD 2005).

\section{Design Issues}

Rosslyn's successes have included the economic transformation made possible by the choice to build around transit. The original goal behind the Rosslyn Sector Plan was economic development, and transit became the basis of the plan not because of its potential to improve air quality or mitigate metropolitan sprawl, but for its economic possibilities. Capitalizing on the Metro system allowed for greater densities, and thus higher returns from commercial property taxes, than would have been possible if, for example, a quarter of buildable land been reserved for thoroughfares and parking. 
Rosslyn's experience in building a high-density commercial core has not been without flaw or controversy. In some ways, Rosslyn has become almost too successful as a site for high-density development, which has pushed aside some of the other TOD design goals such as development at a human scale. Rosslyn is the most built-up area along Metro's Orange Line, and while it boasts some public art and attractive street furniture, the mass of tall concrete buildings and the early lack of attention to pedestrians have made the area less pleasant for those on foot. In addition, space has become so valuable in Rosslyn that many smaller, less profitable uses have been pushed out, further detracting from the vibrancy of street life. While Rosslyn has the ingredients of a successful mixed use area-such as density, accessibility by high-quality transit, and even some appealing architecture- the streetscape lacks the fine details and variety that appeal to pedestrians.

\subsection{Clarendon}

\section{Background}

Clarendon's land-use pattern prior to transit-oriented planning was dominated by small and medium scale retail along the corridor, with a number of detached single-family homes and small apartment buildings in the surrounding areas. While the area was not as run down as Rosslyn during the 1960s and 1970s, the construction of the capital beltway and a number of suburban shopping malls contributed to commercial decline and residential flight from the area (Henry 2006b). Revitalization strategies for Clarendon followed the template laid out by the Rosslyn plan, but with a twist. Instead of focusing on large-scale projects or on dramatically increased density maximums, Clarendon's revitalization has focused on relatively smaller-scale development. A 1984 plan for the area articulated a vision for Clarendon as an "urban village," meaning greater development around its Metro station while maintaining the strong sense of place inherent to the single-family houses and modest apartment buildings further from the station (Parris 1989). The Clarendon plan funneled development initiatives to one focal point - the block that includes the Olmstead Building and Clarendon Metro Park—but did not significantly raise density maximums elsewhere (Henry 2006b). The result has been ongoing commercial revitalization led by small and mid-sized businesses, and simultaneous strengthening of the area's residential neighborhoods.

\section{Design Issues}

A key issue for early planning was revitalizing commercial/retail uses without abandoning the existing lower-height residential character. Conflicts between the parking requirements of local businesses and residents' desire for a quieter neighborhood made parking an early concern, as well; this tension has been partly relieved by transit, but 
still remains. Another issue has been the streetscape of Clarendon; replicating the feel of Rosslyn, for example, would not suit an "urban village." Clarendon planners have learned a great deal from earlier developments, and have stressed that development emphasize a more human scale. Arlington County officials have taken a sophisticated approach to design standards for buildings and pedestrian infrastructure in Clarendon, as demonstrated by façade details, decorative paving, and the design of small public spaces.

Although Clarendon has its share of large office buildings and apartment towers, this area differs greatly from the large-scale development of Rosslyn and Ballston in that it features a significant number of small businesses and single-family houses within walking distance of the station. In addition, while Rosslyn and Ballston are mature zones, Clarendon still has space for expansion and development, making this area a major target for current and future private investment (Henry 2006b). The design challenge for Clarendon is thus still an open one: How to maintain the sense of a small, comfortable place while incorporating further economic development.

\subsection{Ballston}

\section{Background}

Until the 1960s, Ballston was the "downtown" of Arlington County and a major regional hub. But, like so many thriving American centers at the time, its prosperity declined in the face of on-going suburban expansion in the 1970s and 1980s. In response, Ballston began efforts at revitalization in 1980. Planners wanted to take advantage of the construction of Metro's Orange Line, and, as they had in Rosslyn, emphasized mixed-use development. Planners termed their new vision for Ballston a "new Downtown" for Arlington County (Henry 2006c). Since the plan's implementation, Ballston has indeed experienced a rebirth and the station area is pedestrian-friendly and lively, with a mixture of residential and commercial uses. Ballston Metro Center is the signature development, combining seven stories of hotel space, eighteen stories of condominiums, a thirteen-story office building, a mall, an atrium, and a parking garage on one city block at a Metro station (Johnakin 1991: 16). Today, the area's most distinguishing characteristic is the diverse mix of uses in this area. Certainly, there is mixed development at Rosslyn and Clarendon, but office buildings are most prominent at the former, while Clarendon is not nearly as intensively developed. The Ballston area as a whole is an interesting mix of intensive development in the station area and leafy yet compact suburbs nearby. 


\section{Design Issues}

Like Rosslyn, Ballston has significant office development, which tends to crowd out other, less-profitable land uses. The need to keep small businesses and apartments from being priced out of the area as more office buildings are built creates a constant tension. Also like Rosslyn, integrating automobile traffic flows and facilities with the transit-oriented landscape is a challenge. Ballston merchants would obviously like to encourage as many shoppers to come as possible, whether by train or by car, leading to pressure for more parking lots and better traffic circulation. Furthermore, there are a number of large roads near the station that have yet to be integrated into the overall development concept (see Marshall 2004).

On the street level, a number of planning interventions have helped humanize the streetscape, though problems for pedestrians still remain. On the positive side, Welburn Square, across the street from the Metro entrance, boasts lawns, trees, and outdoor dining and hosts a popular art market (Arlington Arts 2007). Sidewalks are typically wide, and many are sheltered by awnings or street trees. On the negative side, the area is still crossed by several wide, suburban-style boulevards that make crossing some streets a difficult task (Marshall 2004). Finally, open space is a design issue in the area; while Ballston has several well-designed open spaces, including the natural garden of the Nature Conservancy, these are not as visible as they might be.

\subsection{The Delmar Loop}

\section{Background}

The Delmar Loop gets its name from the streetcar turnaround that gave the area its identity until the 1960s. During the streetcar era, this area was popular for shopping and entertainment, but it went into decline after the streetcar system ceased operations. In the 1970s, the area recovered somewhat and began to gain a reputation for its diverse collection of small businesses. When MetroLink (the region's light rail transit system) entered operation in the mid 1990s, the area was surviving but not thriving - though the potential was there for a renaissance. Located near the popular Saint Louis landmarks of Washington University and Forest Park, the Delmar Loop had an established stock of small and mid-sized commercial properties, plus a steady presence of college students. The opening of the local MetroLink station has served as a catalyst for economic development, and housing values and commercial rents in the area have increased since its opening (The Loop Special Business District 2006a, 2006b; Bi-State Metro 2006). 


\section{Design Issues}

The Delmar Loop area is an exemplary case study for showing how transit investment and TOD principles can fit into the pre-existing fabric of a city. Unlike the three stations in northern Virginia, or even the following case of Emerson Park (in which transit investment has meant a wholesale change for an area), transit in Delmar Loop was used to enhance and augment pre-existing development (Howland and Dunphy 1996: 44-45). This approach is partly the product of necessity, as the decision to build MetroLink on an old railroad corridor locked in the station locations. The Delmar Loop station is located just off of the main commercial strip, causing some mismatch between the station and the development area, though the distance between the two is not very great.

From a design perspective, the challenge has been how to integrate the transit facilities with the neighborhood as a whole. Streetscape renovations and the use of common signage throughout the area have improved pedestrian access between the station and the popular Delmar Boulevard. The streetscape project widened sidewalks, installed landscaping, and used decorative paving to create a unified theme for the neighborhood, while all-day, on-street parking has been installed to buffer pedestrians from traffic (Bi-State Metro 2006). Gaps remain, however, and much still needs to be done to improve the pedestrian realm. Pedestrians must still traverse some wide cross-streets, and crossing Delmar Boulevard itself near the station is not simple.

As for the station itself, attractive public art (as part of MetroLink's Arts in Transit program) and the widespread use of landscaping have helped soften what would otherwise be an austere experience (Arts in Transit 2006). In addition, land near the station owned by Washington University may well be redeveloped in the future, as may more land to the east of the station (the main Delmar Loop area is to the west).

\subsection{Emerson Park}

\section{Background}

The city of East Saint Louis has long been emblematic of American urban decline (see Kozol 1992). Shifting patterns of industrial production and employment caused an abandonment of the area, while the physical landscape was littered with the remains of industrial production: railroads, dilapidated factories, and industrial pollution. Between 1960 and 1990, the population of East Saint Louis decreased by more than 50 percent, part of a vicious cycle of flight, reduced tax revenues, service decline, more flight, and so on. By the late 1980s, almost half of the residents lived below the federal poverty line and the unemployment rate hovered around 25 percent (Reardon 2003: 3).

The planned construction of MetroLink across the Saint Louis metropolitan area 
in the mid-1990s presented an opportunity for economic development along the corridor, though initial plans had few stops on the Illinois side of the Mississippi River and skipped Emerson Park. Political lobbying by local residents succeeded in persuading MetroLink to rethink the alignment, and the Emerson Park station was completed in 2001. Simultaneously, local residents, planners, and governmental officials have promoted commercial and residential development oriented towards the station. Since its opening, MetroLink has provided nearby residents with better access to job opportunities in central Saint Louis and farther east in Illinois, leading to an increase in private and public investment in the area (ESLARP 2007).

\section{Design Issues}

Emerson Park is the most residentially oriented of the seven case studies, and some of the area's housing redevelopment predates the arrival of the transit station. In 1991, the first phase of housing was completed in the form of the Parsons Place project, which includes 174 mixed-income, townhome-style housing units. This development was selected by Good Jobs First as one of the 25 best examples of TOD that promotes affordable housing and living-wage jobs (Grady and LeRoy 2006). More housing has gone up since Parsons Place, and Emerson Park has added 342 new housing units since 2001 (EPDC 2007). One of these housing developments, River City Place, opened in 2005 and represents the first private housing development built in East Saint Louis in thirty years (Saint Louis Front Page 2001).

Many of the design concerns center around improving the area for residents only, and Emerson Park is spared some of the design difficulties of coordinating transit with mixed-use development. At the same time, however, the area's economic profile presents challenges not faced by other TOD projects (with the exception of Fruitvale to some degree). The entire area has suffered the effects of severe long-term disinvestment including poor maintenance of public infrastructure such as streets and sidewalks. While the TOD area itself is well-lit, with some pleasant open spaces, this positive development sits in a context of significant poverty illustrated by the almost rural feel of adjacent roads with large numbers of vacant lots, little public lighting, poorly maintained houses, and streets where sidewalks, curbs, and gutters are often missing. Thus, while the housing immediately adjacent to the development is well served by streetlights and sidewalks, connections to other areas are missing.

The station area is to the north of a major highway and is highly visible to commuters who can see the new houses and apartments from their cars. However, that highway also blocks redevelopment to the south, again posing questions of how to

connect the pieces. Finally, while the story of Emerson Park's revitalization is one of heroic grassroots action over several decades and against tremendous odds, this story is largely invisible to a casual visitor. Public art might be a medium for interpreting this 
inspiring history and making it accessible to all, as well as encouraging local pride and a sense of community.

\subsection{Fruitvale}

\section{Background}

Like Emerson Park in East Saint Louis, Fruitvale exemplifies the important role that transit can play in revitalizing an economically depressed area (Olson n.d.: 1). Fruitvale was once one of Oakland's poorest neighborhoods, following a familiar pattern of urban disinvestment and decline in the 1960s and 1970s (Unity Council n.d.). In the early 1990s, Bay Area Rapid Transit (BART) planners and local residents and business owners clashed over BART proposals to provide more parking for the Fruitvale Station in order to increase the number of park-and-ride commuters. Locals feared that giving over more land for parking would detract from the commercial and residential potential of the area, and would represent a missed opportunity to use transit to benefit the local area instead of merely to serve out-of-area commuters. Faced with strong local opposition, BART withdrew its plans and entered into a dialogue with the community to try to resolve the disputes (Unity Council, n.d.; FHWA, n.d.).

Although some phases are yet to come, the result of this give and take is the Fruitvale Transit Village: a $\$ 100$ million, 20-acre development project centered on the Fruitvale BART station with neighborhood retail, affordable housing, and places for community interaction on land that had previously been parking lots. Built and managed by a local Community Development Corporation (CDC), the Fruitvale Transit Village demonstrates the benefits of coordinating local economic growth concerns with regional transit planning. This colorful and vibrant mixed-use project has spurred the revitalization of the surrounding neighborhood, a center for Oakland's Latino community. The project totals 255,000 square feet, and contains a variety of uses: 114,500 square feet of office space, 40,000 square feet of neighborhood retail, 47 housing units, a library, a medical clinic, a senior center and a child development center (City of Oakland CEDA 2003). It has received praise as a fine example of how to integrate transit concerns with community and economic development (Renne and Wells 2005: 2).

\section{Design Issues}

The design of the village is attractive, and features ample planter boxes, places to sit, and outdoor tables for coffee and lunch. Ground-level retail forms a corridor leading from the station to International Boulevard, a busy thoroughfare lined with small businesses. Housing is built on the outer edge of the development, as well as above several of the shops in the central part of the development.

Despite the area's attractiveness and the thought given to creating connections and 
providing housing, the Fruitvale Transit Village still faces some challenges. For instance, all parts of the project are within easy access to the station, though one particular design flaw has limited accessibility of the Village for BART users: the parking lots and bus bays are on opposite sides of the station from the transit village, forcing many commuters who use the station as a park and ride facility, or who connect to bus routes, to go to and from their cars or buses without passing the retail area; as a result, the retail portion of the project has had growing pains (Strickland 2006). Combined with the major highway a few blocks south of the station, the placement of the bus bay and parking lot has rendered the development a "180 degree" site.

In this regard, the Transit Village has failed to take complete advantage of the benefits of the station, much to the disappointment of many people who had high hopes for the area. Housing has been another disappointing element of the project; initially, planners wanted several hundred housing units, but due to budget constraints at the time, the initial construction included just 47 . However, 400 more housing units are now in the planning phase and their completion will likely mean a boost for the retail properties in the project (Unity Council n.d.).

\subsection{Oakland City Center/12th Street Station}

\section{Background}

Oakland City Center got its start as an urban renewal project in the late 1960s. Federal urban renewal funds and an extensive use of eminent domain powers allowed for the removal of the existing, modest downtown in hopes of reversing the area's economic decline. The result, by the early 1990s, was a transformation without a renaissance-a landscape dominated by large office buildings and massive parking structures with few shopping opportunities, small parks, or housing units, and little street life. However, despite these shortcomings, it was clear that downtown Oakland also had its charms. The BART station in the middle of downtown has long been one of the most popular in the system, because it is a transfer station accessible by three lines and is the best stop for the thousands of commuters who work in the offices above. A political shift at the state level in favor of more transit funding and coordinated land use planning in

the mid-1990s led to a transformation of the area into a "transit village." This meant a new role for the transit station as a transportation hub and as anchor for a new pedestrian-friendly downtown, along with promoting small-scale retail and residential development (Parker and Mayer 2000).

\section{Design Issues}

A first key step was the partial redesign of the BART station itself. This included adding landscaping, public art, new street lights, and benches. "City Square," a corridor- 
style plaza leading to the BART station, was renovated and is now home to various small businesses, including cafés, lunch places, and small shops. The area is now more inviting to pedestrians, and provides cozy spaces out of the shadows of the large office towers.

The addition of more housing to the area has been the second key to City Center's transformation (Ohland 2001). The push from transit officials to make housing a larger part of the areas near the station has dovetailed with efforts by City of Oakland officials to increase high-density housing in the downtown district as a whole. Ex-mayor Jerry Brown launched the " $10 \mathrm{~K}$ housing Initiative" in 1997 to encourage the construction of 6,000 new housing units and attract 10,000 new residents to Oakland; as of 2006, almost 11,000 units had been built, many within minutes of a BART station (City of Oakland CEDA 2006). With more residents, the small-sale shopping areas have more potential customers, creating in turn an area that is more appealing to possible tenants. In the end, attention to design has been a crucial factor in creating this positive feedback loop and broadening downtown's appeal.

Oakland's downtown is made up of several different parts, including Chinatown and Old Oakland, with distinctive characters; together, these form a vibrant urban center. However, a number of barriers, both tangible and intangible, divide them. Different racial and ethnic groups tend to inhabit different parts of the downtown, demonstrating social barriers. Other barriers, however-such as busy streets, inadequate sidewalks, blank walls, and large buildings such as the convention center-can be addressed through design. Over time, it will be important to deal with these design issues.

\subsection{Assessing the Cases}

In addition to case histories, the cases were assessed using six different methods (see Table 3; Forsyth et al. forthcoming). We analyzed all seven cases using the less laborintensive methods (mapping and the two workshops); in addition, we applied the very labor-intensive methods (urban design score sheet, urban design inventory, and photographic visual assessment) to three of the seven cases. The overall findings are described below.

Urban Design Score Sheet: All three cases (Clarendon, Emerson Park, Fruitvale) were highly imageable (memorable) and had high complexity (variety). Enclosure and transparency (or views to activity) varied according to density, with active Clarendon scoring better than the residential and more spread out Emerson Park. These design differences demonstrate different approaches to TOD.

Urban Design Inventory: Like the score sheet, the inventory demonstrated diversity among TOD areas, though the sites did share some characteristics, notably an absence of "big box" or drive-through uses, impassable roads or freeway ramps, and 
Table 3: Cases Assessed by Method.

\begin{tabular}{lcccccc}
\hline & UDSS & UDI & DW & CRW & GIS & PVA \\
\hline Rosslyn & & & $\checkmark$ & $\checkmark$ & $\checkmark$ & \\
Clarendon & $\checkmark$ & $\checkmark$ & $\checkmark$ & $\checkmark$ & $\checkmark$ & $\checkmark$ \\
Ballston & & & $\checkmark$ & $\checkmark$ & $\checkmark$ & \\
Delmar Loop & & & $\checkmark$ & $\checkmark$ & $\checkmark$ & \\
Emerson Park & $\checkmark$ & $\checkmark$ & $\checkmark$ & $\checkmark$ & $\checkmark$ & $\checkmark$ \\
Fruitvale & $\checkmark$ & $\checkmark$ & $\checkmark$ & $\checkmark$ & $\checkmark$ & $\checkmark$ \\
Oakland City Center & & & $\checkmark$ & $\checkmark$ & $\checkmark$ & \\
\hline
\end{tabular}

CSB = Case Study Background

UDSS = Urban Design Score Sheet

URI = Urban Design Inventory

DW = Design Workshop

CRW = Community Representatitive Workshop

GIS = Geographic Information Systems Mapping

PVA = Photographic Visual Assessment

* The empirical foundation of these principles includes the six

visual assessment methods plus case studies involving area histories.

heavy industries. Clarendon and Fruitvale had many commercial uses; Emerson Park featured front porches and more vacant buildings. While all areas had street trees, Clarendon's were more mature, shading the sidewalks better.

Design Workshops: Designers had a specific viewpoint focused on areas where further design could solve problems, rather than areas that were already working well. They pointed out that good buildings did not always make good places, and conversely that many great places did not have distinctive architecture. While appreciating design, they pointed out that programming and overall planning was as critical as physical design, and they particularly appreciated bohemian or upper-middle class street life with a controlled level of diversity.

Community Representative Workshops: As informed professionals, politicians, and activists, the members of stakeholder groups emphasized factors beyond design including convenience, affordability, community involvement, personal safety, and time- with great places taking decades to create. They highlighted some very specific design issues such as the importance of human-scale details and continuity in pedestrian infrastructure, as well.

GIS-based Analysis of street networks and levels of mixed uses showed that block sizes were similar across the TOD examples with all but Rosslyn having block sizes between 1.5 and 2.5 hectares. Business counts, however, varied greatly. Using the yellow-pages based InfoUSA as the data source, businesses per hectare within 800 me- 
ters of the stations varied from 0.2 in Emerson Park to 39 in Oakland City Center. This, again, shows the variety of TOD types (see Table 4).

Photographic Visual Assessment showed that Fruitvale had the greatest complexity, with Clarendon (more historic) and Emerson Park (more residential) having less complexity. Of course, complexity or visual variety is only one important urban design dimension. However, it provided validation for the findings of the Urban Design Score Sheet that had also measured complexity, finding high complexity in all three areas but identifying Fruitvale as the most complex.

Overall, the various TODs shared some similarities, such as street pattern and imageability, and had some differences, such as levels of commercial uses. These findings mean that while some features are common to many TODs, one size does not fit all.

\section{Good Practice in Urban Design of TOD Projects}

This project examined the role of urban design in Transit-Oriented Development projects emphasizing issues of visual appearance and urban place-making. In addition to the work on measurement in this study, several exemplary reports have drawn together the experiences of designers working on transit-oriented development (Energy Outreach Center and State of Washington 1995; TCRP 1997; FHWA 1998; Greenberg 2004; ITE 2006). This section draws on these sources to provide a summary of measurement and design recommendations. These key sources include:

- The research and practice literature on TOD, which provides general principles typically based on research and more detailed design guidelines, often based on deep experience. Some of these sources are highlighted in Table 1.

- The case study narratives in this study, which provide rich detail about how these specific TODs have been perceived as successes and failures.

- The six urban design assessments, which gave a variety of empirical views-field based and not, qualitative and quantitative.

These recommendations constitute a supplement to previous work on TOD design as outlined above. Specifically, they demonstrate how design has been used to respond to a varied set of practical problems and constraints, adding to Calthorpe's (1993) important work which discussed TOD design in terms of an abstract, ideal type. In addition, these recommendations extend Dittmar and Ohland's (2004) planning process-based study by employing a mixed-methods assessment approach to address possible urban design solutions that may be generalizable to other TODs. 
However, the concept of a "best practice" - some tried-and-true standard method that will invariably deliver good results-is somewhat misleading. It is perhaps better to think of a good design toolkit—or a set of good, not necessarily "best" practices, each with particular effects in particular situations. By selecting different tools from the kit, people responsible for the design of places can mix and match solutions to problems. Good design, then, is not as much a product, some thing that we can all agree on, as it is a process of assessing, selecting, and implementing of a wide variety of individual design interventions.

The rest of this paper focuses on three key topics-Processes, Places, and Facilities - using the seven case studies as illustrations. It provides twelve principles related to good design that draw on both the literature on TOD (see Table 1) and the empirical work in this study (see Table 5).

\subsection{Processes}

\section{Principle 1: Appreciate that planning and developing great places takes time}

Many of the best-loved places in the world are the product of decades if not centuries of development and redevelopment. In this study, groups of designers and community representatives both remarked on the decades-long processes of redevelopment. As design workshop participants stated repeatedly, what looks like fast development is often merely the physical culmination of years of planning, as demonstrated by the three projects in Virginia. Some examples illustrate how the long view shapes one's understanding of a place:

- Downtowns that are dominated by office buildings and have little street life, like the Oakland City Center/12th Street area, became that way over a few decades and might take a few decades to diversify and gain a thriving streetscape once again.

- Parking lots near transit stations can seem to be a waste of space; alternatively, they may be seen as land banks that preserve building sites until more intensive development is possible. Rarely is intensive development marketable in the first few years of the life of a transit system or stop. Fruitvale has been criticized for its placement of parking lots, which confine development. In time, however, this could be valuable land for further expansion, and parking could either be moved farther away or incorporated into a large-scale development. 
JOURNAL OF TRANSPORT AND LAND UsE I:2

Table 4: Case Study Characteristics.

\begin{tabular}{|c|c|c|c|c|}
\hline TOD & $\begin{array}{l}1 \text { mile square } \\
\text { figure-ground }\end{array}$ & $\begin{array}{l}\text { Businesses } \\
\text { per ha } 400 \mathrm{~m} \\
\text { from station }\end{array}$ & $\begin{array}{l}\text { Businesses } \\
\text { per ha } 800 \mathrm{~m} \\
\text { from station }\end{array}$ & $\begin{array}{l}\text { Average } \\
\text { block size } \\
\text { (ha) for } 800 \\
\mathrm{~m} \text { buffer }\end{array}$ \\
\hline Rosslyn (VA) & & 6.1 & 16.9 & 3.34 \\
\hline $\begin{array}{l}\text { Clarendon } \\
\text { (VA) }\end{array}$ & & 4.1 & 11.1 & 1.81 \\
\hline $\begin{array}{l}\text { Ballston } \\
\text { (VA) }\end{array}$ & & 4.5 & 9.6 & 2.21 \\
\hline $\begin{array}{l}\text { Delmar } \\
\text { Loop (MO) }\end{array}$ & & 1.1 & 1.7 & 1.96 \\
\hline $\begin{array}{l}\text { Emerson } \\
\text { Park (IL) }\end{array}$ & & 0.3 & 0.2 & 2.33 \\
\hline $\begin{array}{l}\text { Fruitvale } \\
\text { (CA) }\end{array}$ & & 2.3 & 4.3 & 2.25 \\
\hline $\begin{array}{l}\text { Oakland } \\
\text { City Center/ } \\
\text { 12th St. } \\
\text { Station (CA) }\end{array}$ & $\infty$ & 21.6 & 38.9 & 1.52 \\
\hline
\end{tabular}


Table 5: Key Empirical Sources for Twelve Principles of Good Design.

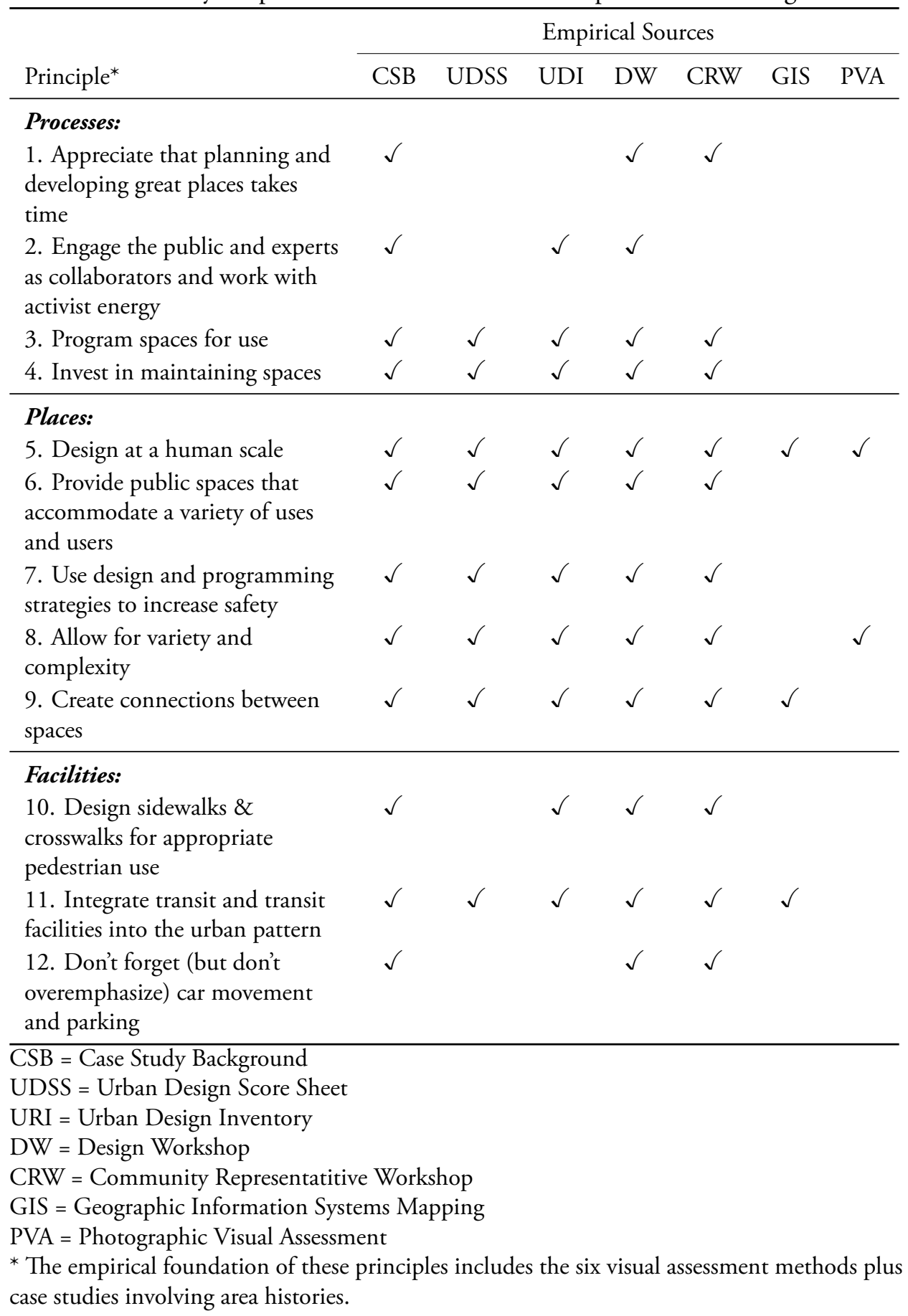




\section{Principle 2: Engage the public and experts as collaborators and work with activist energy}

Community members need to live with the results of development and redevelopment and can be allies or opponents (Nick Wates Associates n.d.; Sanoff 2000; Sarkissian et al. 2003). In Northern Virginia, community groups watched over design issues but bought into the basic planning idea of high density around the train stations. In Emerson Park, activists brought the MetroLink station to their neighborhood. The development of both Emerson Park and Fruitvale involved activism from lower-income groups.

- In long-term redevelopment programs with multiple buildings and projects, it is worth turning local residents and business groups into partners, as has been done in Emerson Park. Their buy-in and local knowledge can be important when weathering inevitable setbacks.

- While community participation processes can slow down design, they can also improve it. Local residents in Fruitvale, for example, were the ones who pushed for a cooperative, design-based solution that benefited both residents and BART. However, it is also important that community members be provided with knowledge about design so that they can be informed partners in these discussions.

\section{Principle 3: Program spaces for use}

A design is a physical space. Programming - that is, providing scheduled activities for spaces-is about use. Successful places have appropriate activities occurring at different times of the day, week, and year. Of course, not all places need to have constant activity, but appropriate programming can increase use, safety, and a sense of place.

- Weekly activities, such as Clarendon's farmer's market or weekend concerts, can bring new people to a place.

- Annual events, such as festivals, provide identity for a place. The Delmar Loop, for example, has initiated an annual street fair called "The Loop in Motion" with live music, dance performances, and art exhibits.

\section{Principle 4: Invest in maintaining spaces}

A number of studies have found that high levels of maintenance are appreciated by users and can make scenes appear more attractive (Nassauer and Larson 2004: 94; Cooper Marcus and Francis 1998). Too often paths, trails, and other pedestrian and cycling facilities are installed without long-term maintenance plans. In addition, as places become popular, wear and tear increases, adding to the maintenance burden. 
- This is especially true in the case of Emerson Park, where declining levels of public maintenance were part of a vicious cycle of neglect and deterioration that afflicted the entire neighborhood. Maintaining the attractive housing and open spaces that have been built since the opening of the transit station is critically important.

\subsection{Places}

\section{Principle 5: Design at a human scale}

Measured explicitly in the urban design audit, referred to by civic representatives, and a key component of the AIA livability principles, human scale is fundamental to creating great places. This does not preclude places with tall buildings and intensive development (AIA 2005; Jacobs and Appleyard 1987; Lynch 1981; Whyte 1980). Rather it has the following characteristics:

- Design so that the areas that people inhabit—such as sidewalks, plazas, and transit stations - are scaled to be usable and interesting to people moving at walking speed. Clarendon, though it is still crisscrossed by roads that detract from the pedestrian environment, is still an improvement over Rosslyn in this regard. Rosslyn could be improved in the future by encouraging more smallscale development to balance out the high-rises.

- Provide human-scale details such as architectural features on buildings, street furniture, and plantings. Fruitvale is one of the most visually intriguing case study sites and features colorful vegetation, public seating, and a mix of building colors that make the whole development area feel inviting.

\section{Principle 6: Provide public spaces that accommodate a variety of uses and users}

Successful transportation environments attract people moving through them. However, public spaces - places where people can stop, sit, and gather-are often ignored in transportation projects, where the emphasis is on moving people around. Public spaces, however, provide a wide array of benefits to individuals and communities alike (Dittmar and Poticha 2004; Dunphy 2004; Whyte 1980). Good public spaces are ones where people like to stop and sit to read a newspaper, eat lunch, or meet friends. As the design workshops held for this study illustrated, they also provide places for people from different groups to either interact or to stake out territory without bothering others. Such spaces can be the settings for organized activities, such as farmer's markets, concerts, festivals and the like. Such activities can be promoted by the inclusion of several design elements: 
- Street furniture can be used to create a sense of a "public living room" by creating a variety of places for people to sit and talk. Benches and ledges at sitting height can be clustered for maximum effect, but can also be distributed to create a series of "nooks" for small groups or individuals, such as in a popular plaza (Ogawa Plaza) near Oakland City Center. Moveable seating, where feasible, allows people the greatest freedom over how to use the space (TCRP 1997: 148).

- Public art can provide a visual clue that a place is special and a good place for gathering, either for a planned activity or just to pass the time.

- Above all, public spaces should be flexible, and allow for many different types of users and activities at different times. For example, a small plaza can be a great lunchtime spot on weekdays, a place for a flea market on Saturday mornings, and then the main stage for an annual festival (TCRP 1997: 143). Parking lots can also be converted to flea markets on the weekend.

\section{Principle 7: Use design and programming strategies to increase safety}

Personal safety is fundamental to the success of public spaces. Programming and use of spaces to ensure safety is vitally important. Many of the case study area had successful formal and informal policing of spaces, which provided "eyes on the street" to increase safety (Jacobs 1961). In addition to programming, there are some design principles that can improve safety and the perception of safety, and thus make the spaces more likely to be used (Wekerle and Whitzman 1995). While urban design for safety is a large topic, issues relevant to this study include:

- Lighting: In order to make places seem cared for and to increase visibility, and thus the potential for positive surveillance, provide adequate lighting in all places where people are meant to be at night. The case of Emerson Park provides a clear positive example, as improved street lighting in the redesigned station area was a major improvement over the adjacent areas.

- Access control: Distinguish between public places where strangers are meant to be and those where they are not through strategies such as fencing, lighting, and landscape. Residential areas adjacent to Emerson Park used fencing and paving to distinguish such areas.

- Visibility: Ensure there are adequate sight lines.

- Movement: Avoid tunnels and narrow paths that potentially funnel pedestrians into the path of an attacker without means of escape; avoid other entrapment spots or isolated areas. 


\section{Principle 8: Allow for variety and complexity}

Places that exhibit a high level of design consistency, as well as those with much variety and complexity, can provide a positive sense of place. However, in the United States, planning regulation tends to make areas uniform and so particular attention is needed to promote visual variety and a diversity of uses (Greenberg 2004).

- Having a common design vocabulary for buildings and public spaces helps to create a strong sense of place by making one area distinct from others. In Fruitvale, a shared color scheme of adobe and beige, highlighted by bright colors like red and turquoise, introduces much needed color into an area dominated visually by warehouses, train tracks, and a freeway. Similarly, Emerson Park features porches and a mix of brick and horizontal siding.

- In the Delmar Loop, however, much of the same effect has been created without the use of building codes and design guidelines. There, the eclectic collection of small-scale retail businesses gives the area a distinct sense of place and makes the area visually interesting.

\section{Principle 9: Create connections between spaces}

While it is important to make great places, it is also important to connect them. All the case study areas had well-connected street patterns as measured in the mapping analysis relevant to their locations, though barriers such as highways or huge parking lots (as in Fruitvale) often limited these good street networks. Moreover, buildings did not always connect well to the outdoors, and sidewalks were not always continuous for pedestrians. Cyclists had even more challenges finding comfortable paths.

- In designing places, make sure that the structure of streets and blocks provides multiple options for pedestrians moving from place to place. Even if vehicular movement is limited, provide pedestrian cut-throughs. In many cases, such as Oakland City Center or Rosslyn, the basic street pattern is already set, but smallscale interventions such as pedestrian-only streets or the introduction of small parks could be a significant improvement.

- Be extremely careful when placing parking lots, which can create de facto barriers for pedestrians (Dunphy et al. 2004: 174-175). Unfortunately, the question of what to do with parking lots has no easy answer; putting parking underground can be very expensive, while doing away with spaces can limit transit usage. Bus bays are another tricky subject. On the one hand, they should be designed for maximum efficiency, but on the other hand, they should not create dangerous areas for pedestrians or detract from the general ambience of the area. 


\subsection{Facilities}

\section{Principle 10: Design sidewalks and crosswalks for appropriate pedestrian use}

Many center city and suburban design projects begin with the needs of pedestrians first and foremost in mind. In some design projects, the problem is how to revive a formerly bustling neighborhood shopping street, and bringing back foot traffic is an important step for such areas. In other cases, designers are tasked with balancing the needs of motorists and pedestrians, while making sure not to sacrifice the safety of either party. Another common problem is accessibility, such as when a highway or railroad tracks create an obstacle for anyone not in a car.

A number of design elements can help make waking safer, more pleasant and more convenient. These include:

- Buffers that separate moving traffic from pedestrians. In the Delmar Loop, simply allowing for on-street parking provided separation of sidewalk from traffic.

- Various types of landscaping — such as trees, flower boxes or strips of grass—can also serve this function while simultaneously improving the look of the street (FHWA 1998: 83).

- Sidewalk dining, as in Clarendon, encourages pedestrian activity and can create a sense of safety and vitality in some areas (Greenberg 2004: 71).

- At crosswalks, special features (such as the use of different materials or curb bulb-outs) help to distinguish pedestrian territory from driver territory. This approach has been used effectively in the northern part of the Fruitvale project, where busy International Boulevard leads into the TOD project. This helps slow traffic and cues pedestrians and drivers that they are approaching a special area.

\section{Principle 11: Integrate transit and transit facilities into the urban pattern}

The design of bus and rail facilities is complicated, as various needs and constraints must be properly balanced. A transit facility is a transition point between various modes, as people park cars and bikes and walk before heading on to mass transit. People also transfer between routes or types of transit. Compared to traditional transit planning, TOD creates an even more diverse set of demands and expectations on transit facilities. These challenges also bring opportunities, however. Transit naturally brings people together, a key goal of urban designers seeking to promote street life. Transit can also serve as the impetus for economic or community development in a place, as investments in transit offer a chance to pursue other, complementary goals. Good design elements for transit facilities include: 
- Linking the transit facility with the surrounding area, especially in cases where the transit facility may be somewhat removed from the geographical center of the TOD. The Oakland City Center/12th Street station is underground, so opening up the staircases and escalator area helped to make travel between the station and the street more pleasant. Building a small pedestrian-only plaza above the station also helped. In the Delmar Loop area, the train station is actually at one end of the development; attractive landscaping and signage have been used to connect it with the main shopping street.

- Providing amenities for transit riders. These include places to sit, public telephones, and shelter from the rain, sun, and wind. Maps showing the station area, the surrounding neighborhood, and where to find connections to other transit routes are also important. Fruitvale has a pleasant area just in front of the station where people can sit, have coffee, or shop before or after their train ride.

\section{Principle 12: Don't forget (but don't overemphasize) car movement and car parking}

A number of design elements for streets can be used to create more walkable places, while simultaneously making the environment safe for drivers. Many of these entail slowing traffic, or restricting it to a level that is suitable level for the area. Reduced levels of service should be compensated for in other ways, however, such as by enhancing traffic capacity on parallel or nearby streets. Design solutions include:

- Wide streets and high vehicle speeds create physical and psychological barriers for pedestrians. Slowing vehicle speeds, by narrowing the roadways, enforcing lower speed limits, installing speed tables or speed bumps, is needed to create more pedestrian friendly areas. Medians are another way to narrow a roadway and add many benefits. They can serve as pedestrian islands to provide refuge when crossing wide streets and boulevards. On the western side of the Fruitvale project, a median strip was placed in the middle of a busy street and helped to lower vehicle speeds.

As ubiquitous as cars are on the American landscape, they are not so common as parking places. Figuring out places and ways to store cars when they are not in use, while still making parking spots convenient for shoppers, visitors and employees, is a major challenge of urban design (Dunphy et al. 2004). When not placed well, parking lots and structures can sever neighborhoods and create dead spaces. Good design can avoid these problems, and also contribute to other goals.

- Allowing for on-street parking, as was done in Delmar Loop, helps create more walkable streets by making pedestrians safer from traffic. 
- Enclosed parking facilities, such as those in Rosslyn, Ballston, and Oakland City Center, provide spaces for cars without severing the traffic pattern for pedestrians to the same degree that surface-level parking lots do. However, space reserved for parking, whether in parking garages or parking lots, removes space that could be used for housing, shopping or recreation, for example.

- Pooling parking facilities, so that different types of visitors can use them throughout the day, can be a good solution for mixed-use areas. In the case study regions, park-and-ride lots associated with transit were used for nighttime theater parking and for weekend markets.

\section{Conclusion}

Transit Oriented Development has been increasingly promoted as a solution to the problems of urban growth in the United States. If TOD is to be widely adopted as a real alternative to automobile-oriented urban patterns, it needs to capture a broad market in terms of household types, income levels, and regional locations. Success in this endeavor will be, at least in part, a function of the livability, accessibility, and attractiveness created by careful physical planning and good urban design.

This paper has demonstrated that there are many options for creating a well-designed transportation environment and multiple solutions to solving site-specific problems. The case studies, representing a variety of TODs, show successful elements of urban design that other projects may copy or adapt in part for design and development processes, place-making approaches, and facility design and management.

At the same time, the case studies also highlight pitfalls to avoid, such as " 180 degree" stations. They stress some things to consider in general TOD design-for example, that good design takes time. This study also demonstrates a range of methods for assessing urban design features of TODs. While using all six assessment methods on multiple cases is time consuming, they can be relatively easily applied in simpler circumstances.

How future projects solve the multiple and complex design challenges inherent in TOD will depend on the particular circumstances surrounding each project, and on the ability of designers, policymakers, engineers, and local citizens to balance competing objectives. Overall, physical design — both in terms of visual quality and livability-is an important aspect of making TOD projects work and is worthy of further attention.

\section{Acknowledgments}

The authors thank Center for Transportation Studies director Robert Johns, who served as the principal investigator for the umbrella project of which this was a sub-study. An- 
drew Goldberg from the AIA provided a great deal of assistance in setting up workshops with AIA members and others. Katie Thering, Laura Baum, Lukas Van Sistine, Wendy Sarkissian, Kristen Day, Amanda Johnson, and Bonnie Hayskar also made valuable contributions to this research.

\section{References}

Adams, A. 1994. St. Louis Metrolink: Changing the rules of transit design. Places 9 (2): 88-90.

American Institute of Architects (AIA) 2002. Arlington County, Va., for smart growth in the Rosslyn-Ballston Metro corridor. In: American Institute of Architects [database online]. Washington, DC, 2002 [cited November 4 2006]. Available from http://www.aia.org/aiarchitect/thisweek02/tw1122/1122tw2smartgrowth_ oe.htm.

American Institute of Architects (AIA) 2005. Livability 101. American Institute of Architects, Washington, DC.

Arlington Arts. Art market at Ballston. In: Arlington Arts [database online]. Arlington, VA, 2007 [cited April 17 2007]. Available from http://www.arlingtonarts. org/arts_comm/artmarket.htm.

Arlington County (Virginia) Department of Community Planning, Housing and Development (CPHD) 2005. Development in the Metro corridors (1960-2005): Development summary for the Rosslyn Metro station area. Arlington County Department of Community Planning, Housing and Development, Arlington, VA.

Arts in Transit. Metro arts in transit: Mission. In: Arts in Transit [database online]. St. Louis, MO, 2006 [cited November 4 2006]. Available from http://www. artsintransit.org/pages/mission.html.

Bernick, M. and R. Cervero 1997. Transit villages in the 21st century. McGraw-Hill, New York.

Bi-State Development Agency of the Missouri-Illinois Metropolitan District (Metro) 2006. Delmar streetscape \& transit plaza. In: Bi-State Development Agency of the Missouri-Illinois Metropolitan District [database online]. [cited November 4 2006]. Available from http://www.metrostlouis.org/InsideMetro/CapitalProjects/ buscenters/delmar.asp.

Boarnet, M., et al. 2006. The Minnesota inventory to measure built environments: Reliability tests. American Journal of Preventative Medicine 30 (2): 153-259.

Calthorpe, P. 1993. The next American metropolis: Ecology, community and the American dream. Princeton Architectural Press, New York.

Calthorpe, P. and W.B. Fulton 2001. The regional city: Planning for the end of sprawl. Island Press, Washington, DC. 
Cervero, R. 1998. The transit metropolis: A global inquiry. Island Press, Washington, DC.

Cervero, R. 1994. Rain transit and joint development: land market impacts in Washington, D.C. and Atlanta. Journal of the American Planning Association 60 (1): 83-94.

Cervero, R., et al. 2002. Transit-oriented development and joint development in the United States: A literature review. Transportation Research Board, National Research Council, Washington, DC.

City of Oakland Community and Economic Development Agency (CEDA) 2006. $10 \mathrm{~K}$ housing initiative. In: City of Oakland Community and Economic Development Agency (CEDA) [database online]. [cited November 17 2006]. Available from http://www.business2oakland.com/main/10kdowntownhousinginitiative.htm

City of Oakland Community and Economic Development Agency (CEDA) 2003. Oakland leads nation in transit-oriented development. City of Oakland Community and Economic Development Agency, Oakland, CA.

Cooper Marcus, C., and C. Francis 1998. People places: design guidelines for urban open space. 2nd ed. Van Nostrand Reinhold, New York.

Cooper Marcus, C., and W. Sarkissian 1986. Housing as if people mattered: Site design guidelines for medium-density family housing. University of California Press.

Day, K., M. Boarnet, M. Alfonzo, and A. Forsyth 2006. The Irvine-Minnesota inventory to measure built environments: Development. American Journal of Preventive Medicine 30 (2): 144-152.

Dittmar, H. and G. Ohland, eds. 2004. The new transit town: Best practices in transit-oriented development. Island Press, Washington, DC.

Dittmar, H, and S. Poticha 2004. Defining transit-oriented development: The new regional building block. In: H. Dittmar and G. Ohland, eds., The New Transit Town: Best Practices in Transit-Oriented Development. Island Press, Washington, DC.

Duany, A., E. Plater-Zyberk, and J. Speck 2000. Suburban nation: the rise of sprawl and the decline of the American Dream. 1st ed. North Point Press, New York.

Dumbaugh, E. 2004. Overcoming financial and institutional barriers to TOD: Lindbergh Station case study. Journal of Public Transportation 7 (3): 43-68.

Dunphy, R., D. Myerson, and M. Pawlukiewicz 2004. Ten principles for developing around transit. In: R. Dunphy, ed., Developing around transit. Urban Land Institute, Washington, DC.

Dunphy, R.T. 2004. Developing around transit: Strategies and solutions that work. Urban Land Institute, Washington, DC.

East Saint Louis Action Research Project (ESLARP). East Saint Louis action research project. In: College of Fine and Applied Arts, University of Illinois at Urbana- 
Champaign [database online]. Urbana-Champaign, IL, 2007 [cited April 17 2007]. Available from http://www.eslarp.uiuc.edu/.

Emerson Park Development Corporation (EPDC). Emerson Park Development Corporation. In: Emerson Park Development Corporation [database online]. East Saint Louis, IL, 2007 [cited April 17 2007]. Available from http://www.meptv. com/epdctest/contact.htm.

Energy Outreach Center and State of Washington 1995. Redevelopment for livable communities. Energy Outreach Center and Washington State Energy Office, Olympia, WA.

Ewing, R., et al. 2005. Measuring urban design qualities related to walkability. Final Report prepared for Active Living Research, Robert Wood Johnson Foundation.

Ewing, R., et al. 2006. Identifying and measuring urban design qualities related to walkability. Journal of Physical Activity and Health 3 (Supplement 1): S223-S240.

Forsyth, A., ed. 2005. Environment and physical activity: GIS protocols. University of Minnesota Design Center.

Forsyth, A., J. Jacobson, and K. Thering (forthcoming). Six assessments of the same scenes: Comparing views of urban design. Journal of Urban Design.

Forsyth, A., J. Jacobsen, and K. Thering 2007. Moving design. Executive Summary. Minneapolis: University of Minnesota. available at http://www.cts.umn.edu/ Publications/ResearchReports/reportdetail.html?id=1530

Grady, S., and G. LeRoy 2006. Making the connection: Transit-Oriented Development and Jobs. Good Jobs First, Washington, DC.

Greenberg, E. 2004. Regulations shape reality: Zoning for transit-oriented development. In: H. Dittmar and G. Ohland, eds., The new transit town: Best practices in transit-oriented development. Island Press, Washington, DC.

Hayden, D. 2003. Building suburbia: Green fields and urban growth, 1820-2000. 1st ed. Pantheon Books.

Henry, K. 2006a. Rosslyn Metro station area: Development in the Metro corridorsn 1960-2005. in Arlington County (Va.) Department of Community Planning, Housing \& Development [database online]. [cited November 4 2006]. Available from http://www.co.arlington.va.us/Departments/CPHD/planning/data_maps/ metro/rosslyn/\#intro.

Henry, K. 2006b Clarendon Metro station area: Development in the Metro corridors 1960-2005. In: Arlington County (Va.) Department of Community Planning, Housing \& Development [database online]. [cited November 4 2006]. Available from http://www.co.arlington.va.us/Departments/CPHD/planning/data_maps/ metro/clarendon/\#intro.

Henry, K. 2006c. Ballston Metro station area: Development in the Metro corridors 1960-2005. In: Arlington County (Va.) Department of Community Planning, Housing \& Development [database online]. [cited November 4 2006]. Available 
from http://www.co.arlington.va.us/Departments/CPHD/planning/data_maps/ metro/clarendon/\#intro.

Howard, E. 1985. Garden cities of to-morrow. New revised ed. Eastbourne, East Attic Books, Sussex, UK.

Howland, L., and R.T. Dunphy 1996. Transit sparks redevelopment in St. Louis and Chicago. Urban Land 55 (7): 43-46.

Institute of Transportation Engineers, et al. 2006. Context sensitive solutions in designing major urban thoroughfares for walkable communities. Washington, DC: Institute of Transportation Engineers, Projected Date: 0604.

Jacobs, A., and D. Appleyard 1987. Toward an urban design manifesto. Journal of the American Planning Association 53, 112-120.

Jacobs, A.B. 1993. Great streets. MIT Press.

Jacobs, J. 1961. The death and life of great American cities. Random House.

Johnakin, S.G. 1991. Declarations for interconnected mixed-use projects. Urban Land 50 (11): 16-21.

Kay, J.H. 1998. Asphalt Nation: How the Automobile took over America, and how we can take it back. University of California Press.

Kozol, J. 1992. Savage inequalities: Children in America's schools. HarperPerennial.

Leach, D. 2004. The Arlington case study: Rosslyn-Ballston corridor. In H. Dittmar and G. Ohland, eds., The new transit town: Best practices in transit-oriented development. Island Press, Washington, DC.

Lynch, K. 1981. A theory of good city form. MIT Press.

Marshall, A. 2004. Love (and hate) that Metro [Washington, D.C.]. Planning 70 (2): $18-23$.

Nasar, J.L. 1998. The evaluative image of the city. Sage Publications, Thousand Oaks, CA.

Nassauer, J.I., and D. Larson 2004. Aesthetic initiative measurement system: A means to achieve context sensitive design. Transportation Research Record 1890: 88-96.

Nick Wates Associates. Community planning handbook: Methods. In: Nick Wates Associates [database online]. [cited February 28 2008]. Available from http: //www.communityplanning.net/methods/methods.htm.

Ohland, G. and Great American Station Foundation 2001. Transit-oriented development in four cities. Chicago, IL.

Olson, L. (n.d.) Fruitvale BART community redevelopment project. Mobility Partners, Washington, DC.

Parker, T., and D. Mayer 2007. California transit-oriented development (TOD) searchable database. In: California Department of Transportation [database online]. [cited April 17 2007]. Available from http://transitorienteddevelopment.dot.ca. gov/miscellaneous/NewHome.jsp. 
Parris, M. 1989. The Rosslyn-Ballston corridor: Early visions. Arlington County (Va.) Department of Community Planning, Housing, and Development.

Reardon, K.M. 2003. Riding the rails. National Housing Institute, Montclair, NJ.

Renne, J.L. et al. 2005. Transit-oriented development: Developing a strategy to measure success. Transportation Research Board.

Saint Louis Front Page 2001. Parsons Place in Emerson Park. Moore Design Group, Saint Louis, MO.

Sanoff, H. 2000. Community participation methods in design and planning. Wiley, New York.

Sarkissian, W., A. Cook, and K. Walsh (2003). Community participation in practice: A practical guide. Institute for Sustainability and Technology Policy, Murdoch University, Murdoch, Australia.

Seigman, P. 2003. Is it really TOD? Planning 69 (5): 17.

Sheppard, S. and S. Newman 1979. Prototype visual impact assessment manual. State University of New York, Syracuse, College of Environmental Science and Forestry.

Southworth, M. 1997. Walkable communities? An evaluation of neotraditional communities on the urban edge. Journal of the American Planning Association 63 (1): $28-44$.

Stamps, Arthur III 1999. Demographic effects in environmental aesthetics: A metaanalysis. Journal of Planning Literature 14 (2): 155-75.

Strickland, E. 2006. Ghost town: What if they built the future and no one came? East Bay Express, January 4.

The Loop Special Business District 2006b. The Loop in Motion festival. In: The Loop Special Business District [database online]. [cited November 4 2006]. Available from http://www.ucityloop.com/loopinmotion/index.html.

The Loop Special Business District 2006a. University City St. Louis: The Delmar Loop. In: The Loop Special Business District [database online]. [cited November 4 2006]. Available from www.ucityloop.com.

Transit Cooperative Research Program 1997. The role of transit in creating livable metropolitan communities. TCRP Report 22. National Academy Press, Washington, DC.

Tumlin, J., A. Millard-Ball, P. Seigman, and C. Zucker 2003. How to make transitoriented development work: Number one: Put the transit back. Planning 69 (5): $14-19$.

United States Federal Highway Administration (FHWA) n.d. Partnerships, enhancements, and public involvement: Fruitvale Transit Village project. United States Federal Highway Administration.

United States Federal Highway Administration (FHWA) 1998. Flexibility in highway design. United States Federal Highway Administration. 
United States Federal Highway Administration (FHWA) 1988. Visual Impact Assessment for Highway Projects. Vol. FHWA-HI-88-054. United States Federal Highway Administration.

Unity Council n.d. Fruitvale Village Project Overview. Unity Council, Oakland, CA. Urban Places Project 2000. The YouthPower Guide: How to Make Your Community Better. University of Massachusetts Extension, Amherst, MA.

Ward, R. 1991. Planning for growth in Arlington County, Virginia. Urban Land 50 (1): 2-6.

Warner, S.B. 1962. Streetcar Suburbs: The Process of Growth in Boston, 1870-1900. Harvard University Press.

Wekerle, G.R., and C. Whitzman 1995. Safe Cities: Guidelines for Planning, Design, and Management. Van Nostrand Reinhold, New York.

Whyte, W.H. 1980. The Social Life of Small Urban Spaces. Conservation Foundation, Washington, DC.

Zucker, C. 2003. TOD is working in suburban DC. Planning, May 18. 